\title{
Nutritional and Phytochemical Profile of Niger Cultivated Date Palm (Phoenix Dactilyfera $L$ )
}

\author{
Sarah Olufunso Oni*, Abiola Muhammad Adeosun, Olusola Abiola Ladokun, \\ Osasenaga Macdonald Ighodaro, Omotayo Moshood Oyedele
}

Department of Biochemistry, Lead City University, Ibadan, Nigeria

\section{Email address:}

sallyufan@yahoo.com (S. O. Oni)

\section{To cite this article:}

Sarah Olufunso Oni, Abiola Muhammad Adeosun, Olusola Abiola Ladokun, Osasenaga Macdonald Ighodaro, Omotayo Moshood Oyedele. Nutritional and Phytochemical Profile of Niger Cultivated Date Palm (Phoenix Dactilyfera L). Journal of Food and Nutrition Sciences. Vol. 3, No. 3, 2015, pp. 114-118. doi: 10.11648/j.jfns.20150303.16

\begin{abstract}
The chemical constituents available in plants have been reported to vary with the geographical location of the plants. This investigation assessed the nutritional and phytochemical profile of Niger date palm (Khaokhara) fruit and sought to determine any uniqueness of Niger cultivate Date palm relative to Date palms cultivated in other regions. Standard procedures as described by AOAC were employed in the analyses. The moisture, crude protein and fat contents were determined to be $13.40,2.67$ and $0.70 \mathrm{~g} / 100 \mathrm{~g}$ respectively while the dietary fibre, ash, and carbohydrate values were respectively estimated as $2.13,3.29$ and $76.95 \mathrm{~g} / 100 \mathrm{~g}$. The antioxidant vitamins present in the fruit were also evaluated; ascorbic acid $(0.5 \mathrm{mg} / 100 \mathrm{~g})$, carotenoid $(15.5 \mu \mathrm{g} / 100 \mathrm{~g})$ and Tocopherol $(0.00 \mathrm{mg} / 100 \mathrm{~g})$. Phytochemical screening of the fruit showed that it contained alkaloids $(1.59 \mathrm{~g} / 100 \mathrm{~g})$, anthraxquinones $(0.17 \mathrm{~g} / 100 \mathrm{~g})$, flavonoids $(3.36 \mathrm{~g} / 100 \mathrm{~g})$, tannins $(0.69 \mathrm{~g} / 100 \mathrm{~g})$, saponins $\left(1.37 \mathrm{x} 10^{-}\right.$ $\left.{ }^{3} \mathrm{~g} / 100 \mathrm{~g}\right)$ and terpenoids $\left(1.97 \times 10^{-3} \mathrm{~g} / 100 \mathrm{~g}\right)$. Other phytochemicals that were detected but not quantified are phlobatanins and steroids. This fruit is very rich in potassium $(360.79 \mathrm{mg} / 100 \mathrm{~g})$ and contains appreciable amount of calcium and phosphorus (37.45 and $27.30 \mathrm{~g} / 100 \mathrm{~g}$ respectively). Overall, the data obtained from this investigation did not show much difference between Niger Date palm fruit and other previously studied cultivars vis-a-vis phytochemical and nutritional compositions.
\end{abstract}

Keywords: Niger, Date Palm, Proximate Analysis, Phytochemical Analysis, Minerals

\section{Introduction}

Date palm (Phoenix dactilifera L.) belongs to the Palmae (Arecaceae) family. They are extensively cultivated in the Middle-East and Northern-African countries including Niger Republic. Date palm fruits are considered as staple fruits and important component of diet in most arid and semi-arid regions of the world [1,2]. They are berries rich in carbohydrates with abundant simple sugars like glucose and fructose, but low in fats and entirely lack starch [1, 3, 4]. They are a good source of fibre and are also rich in vitamins like riboflavin, biotin, thiamine, ascorbic and folic acid that are essential to the body. Date palms are used for flavouring foods and beverages. Due to its longevity, nutritional value and great yields, date palm is often regarded as 'tree of life' [5]. Different cultivars of date palm fruits have been reported to be rich in calcium, iron, copper, cobalt, magnesium, fluorine, manganese, phosphorus, potassium, sodium, boron, sulfur, zinc and selenium [3, 6]. Many studies around the world have established the richness of date palms fruits in bioactive compounds such as sterols, saponins, terpenoids, flavonoids, and anthocyanins However, results on nutritional and phytochemical components of different cultivars of date palms varies with the locations from which they were harvested. In this study, we accessed the phytochemical profile and nutritional value of Niger cultivated date palm fruits and sought to determine any uniqueness of Niger cultivate Date palm fruits relative to Date palm fruits cultivated in other regions.

\section{Methods and Materials}

Fresh date palm fruits were procured from date farm in Niger republic and were transported at room temperature to laboratory of the department of Biochemistry, Lead City University, Ibadan, Nigeria. The fruits were dried at room temperature, deseeded and blended into paste using Nakkai 
blender MX-3180. Chemicals and reagent used in this study were purchased from sigma company USA.

\section{Proximate Analysis}

Standard methods by AOAC were used to determine the carbohydrate content, crude fats, crude fibres, protein, ash and moisture content of the sample [7]. Ascorbic acid was estimated using titration method developed by Harris and Ray [8]. Vitamin A (Carotenoid) was evaluated following standard method of Arnon [9].

\section{Gross Energy}

The formula used for gross energy is as follows:

$$
\begin{gathered}
\mathrm{GE}(\mathrm{Kcal} / \mathrm{g})=5.72 \times(\text { protein })+9.5(\mathrm{fat})+4.79(\text { fibre })+ \\
4.03(\text { carbohydrate }) \text { Garrett and Johnson }[10] .
\end{gathered}
$$

\section{Elemental Analysis}

100 ppm stock solution of the $\mathrm{K}, \mathrm{Mg}, \mathrm{Ca}, \mathrm{Na}, \mathrm{Fe}, \mathrm{Zn}, \mathrm{Pb}$, were prepared by dissolving required amount of salts in distilled water for elemental analysis of the sample. The sample was digested according to perchloric-acid digestion method [11]. $0.25 \mathrm{~g}$ of the sample was taken into $50 \mathrm{~mL}$ flask, $6.5 \mathrm{~mL}$ of mixed acids solution (Nitric acid, Sulfuric acid, perchloric acid in ratio 5:1:0.1) was added to it and boiled in a fume hood on hot plate till the digestion was completed which was indicated by white fumes coming out from the flasks. Digested sample was allowed to cool and then transferred into $50 \mathrm{~mL}$ volumetric flask, by rinsing volume with distilled water. The digested sample was filtered through Whatmann filter paper (No 42). The elemental concentrations in the sample (filterate) were determined using Shimadzu AA-670 Atomic Absorption Spectrophotometer as follows:

Nutrient Cation $=($ Extract - Blank $) \times \mathrm{A} / \mathrm{W} \times$ Dilution Factor

(Ppm)

\section{$A=$ Total volume of extract $(\mathrm{mL}), W=$ Weight of dry plant}

\section{Phytochemical Screening}

Chemical tests were carried for preliminary Phytochemical screening of date palm fruit using standard procedure by Sofowora [12], Trease and Evans [13] and Harbone [14]. The fruit extract was screened for the presence of tannins, phlobatinins, saponins, flavonoids, terpenoids, anthraquinones, cardiac glycosides, coumarine and alkaloids.

\section{Determination of Alkaloid in Sample}

Five hundred milligram $(500 \mathrm{mg})$ sample was weighed into a $250 \mathrm{~mL}$ beaker and $200 \mathrm{~mL}$ of $10 \%$ acetic acid in ethanol was added to it, covered and allowed to stand for $4 \mathrm{~h}$. This was then filtered and the extract was concentrated on a water bath to one-quarter of the original volume. Concentrated ammonium hydroxide was added drop wise to the extract until the precipitation was completed. The whole solution was allowed to settle and the precipitate was collected and washed with dilute ammonium hydroxide solution and then filtered, dried and weighed [14].

\section{Determination of Saponin Sample}

Fifty milligram $(50 \mathrm{mg})$ of the sample was weighed into a conical flask and $100 \mathrm{~cm}^{3}$ of $20 \%$ aqueous ethanol was added to the sample. The sample was heated over a hot water bath for $4 \mathrm{~h}$ with continuous stirring at about $55^{\circ} \mathrm{C}$. The mixture was filtered and the residue re-extracted with another $200 \mathrm{~mL}$ $20 \%$ ethanol. The combined extracts were reduced to $40 \mathrm{~mL}$ over water bath at about $90^{\circ} \mathrm{C}$. The concentrated filtrate was transferred into a $250 \mathrm{~mL}$ separating funnel and $20 \mathrm{~mL}$ of diethyl ether was added and shaken vigorously. The aqueous layer was recovered while the ether layer was discarded. The purification process was repeated. $60 \mathrm{~mL}$ of n-butanol was added. The combined n-butanol extracts were washed twice with $10 \mathrm{~mL}$ of $5 \%$ aqueous sodium chloride. The resultant solution was heated in a water bath. After evaporation the samples were dried in the oven to a constant weight the weight of saponin were determined in the samples [15].

\section{Determination of Flavonoid in Sample}

Fifty milligram $(50 \mathrm{mg})$ of the sample was extracted repeatedly with $100 \mathrm{~mL}$ of $80 \%$ aqueous methanol at room temperature. The solution was filtered through Whatmann filter paper No $42(125 \mathrm{~mm})$. The filtrate was later transferred into a crucible and evaporated into dryness over a water bath and weighed to a constant weight [16].

\section{Determination of Anthraquinone in Sample}

Fifty milligram (50 mg) of the sample was soaked in 50 $\mathrm{mL}$ of distilled water for 16 hours. The suspensions of the samples were heated in water bath at $70^{\circ} \mathrm{C}$ for one hour. After the suspensions were cooled, $50 \mathrm{~mL}$ of $50 \%$ methanol was added to the sample, followed by filtration. The spectrophotometric value of the filtrate was read at a wavelength of $450 \mathrm{~nm}$ and compared with those of standard solutions containing $1 \mathrm{mg} / 100 \mathrm{~mL}$ of alizarin and purpurinrespectively [17].

\section{Determination of Tannins in Sample}

Fifty milligram $(50 \mathrm{mg})$ of the sample was weighed into a $250 \mathrm{~mL}$ beaker. $50 \mathrm{~mL}$ of distilled water was added and stirred for $1 \mathrm{~h}$ on a mechanical shaker. The sample was filtered into a $50 \mathrm{~mL}$ volumetric flask and made up to the meniscus mark. $5 \mathrm{~mL}$ of the filtered sample was measured into test tube containing $2 \mathrm{~mL}$ of $0.1 \mathrm{M} \mathrm{FeCl}_{3}$ in $0.1 \mathrm{M} \mathrm{HCl}$ 
and $0.008 \mathrm{M} \mathrm{K}_{3} \mathrm{Fe}(\mathrm{CN})_{6}(1: 1)$. The absorbance was measured with a spectrophotometer at $120 \mathrm{~nm}$ wavelength within 10 $\min [18]$

\section{Determination of Terpenoids in Sample}

One gram $(1 \mathrm{~g})$ of the sample was added to $10 \mathrm{~mL}$ of petroleum ether and allowed to extract for $15 \mathrm{mins}$. The solution was filtered and read at an absorbance of $420 \mathrm{~nm}$ [19].

\section{Statistical Analysis}

All determinations were conducted in triplicate and statistical analysis was performed using SPSS software 16.0 (SPSS Inc., Chicago, IL). Results were recorded as Mean \pm SD

\section{Results}

The proximate composition of date palm fruit is shown in Table 1. The fruit contains high level of carbohydrate $(76.95 \mathrm{~g} / 100 \mathrm{~g})$.

Table 1. Proximate composition of Niger Date palm fruit.

\begin{tabular}{ll}
\hline Nutritional components & Fruit(g/100g) \\
\hline Moisture Content & $13.40 \pm 0.10$ \\
Crude Protein & $2.67 \pm 0.08$ \\
Crude Fat & $0.70 \pm 0.01$ \\
Crude Fibre & $2.13 \pm 0.01$ \\
Total Ash & $3.29 \pm 0.02$ \\
Carbohydrate & $76.95 \pm 0.95$ \\
\hline
\end{tabular}

Results are means of triplicate determinations \pm standard deviation

Table 2. Antioxidant vitamins in Niger Date palm fruit.

\begin{tabular}{ll}
\hline Nutritional components & Fruit(mg/100g) \\
\hline Ascorbic acid & $0.5 \pm 0.00$ \\
Carotenoid & $1.55 \times 10^{-2} \pm 0.00$ \\
Tocopherol & $0.0 \pm 0.00$ \\
\hline
\end{tabular}

Results are means of triplicate determinations \pm standard deviation

Niger Date palm fruit was found to contain ascorbic acid and carotenoid but lack tocopherol as shown in Table 2.

Table 3. Mineral compositions of Niger date palm fruit.

\begin{tabular}{ll}
\hline Minerals & Fruit $(\mathbf{m g} / \mathbf{1 0 0 g})$ \\
\hline Sodium & $0.73 \pm 0.01$ \\
Potassium & $360.79 \pm 39.21$ \\
Calcium & $37.45 \pm 0.25$ \\
Magnesium & $0.45 \pm 0.00$ \\
Iron & $2.32 \pm 0.00$ \\
Phosphorus & $27.30 \pm 0.00$ \\
Zinc & $0.69 \pm 0.25$ \\
\hline
\end{tabular}

The values of mineral elements present in Niger Date palm fruit are shown in Table 3. Potassium was observed to be outstandingly high in Niger date palm fruit $(360.79 \mathrm{mg} / 100 \mathrm{~g})$ when compared to other mineral elements detected in the fruit. Calcium and phosphorous in the fruit were also of reasonable amounts when compared to other minerals like sodium, zinc and magnesium.

Results from qualitative phytochemical screening revealed the presence of alkaloids, anthraquinones, phenolic compounds, phlobatinins, saponins, steroids, tannins and terpenoids, Quantitative estimation of the phytochemicals showed relatively large amounts of flavonoids and alkaloids in Niger date fruit (Table 4).

Table 4. Phytochemical component of Niger Date palm fruit.

\begin{tabular}{ll}
\hline Phytochemicals & Fruit $(\mathbf{m g} / \mathbf{1 0 0 g})$ \\
\hline Alkaloids & $1591.0 \pm 15.39$ \\
Flavonoids & $3360 \pm 0.00$ \\
Anthraquinone & $169.2 \pm 15.21$ \\
Saponin & $1.37 \pm 0.10$ \\
Terpenoids & $1.97 .0 \pm 0.12$ \\
Tannin & $685.0 \pm 0.00$ \\
\hline
\end{tabular}

\section{Discussion}

Date fruits are considered as staple fruits in Arabian Peninsula and they are widely cultivated in semi-arid regions including Niger republic. Phytochemical and nutritional compositions of Date palm fruits reported by different studies vary $[2,4,20]$ and difference in the region of cultivation has been implicated [3, 21, 22]. Our study focused on the nutritional and phytochemical profile of Niger cultivated date palm fruit. The result of our study was a bit related to studies conducted on date palm fruit harvested from Oman, Nigeria and Saudi Arabia [1, 2, 4, 22].

The date fruit examined in this study showed high carbohydrate content hence can be considered a good source of energy. Carbohydrate contributes the greatest amount of energy required by man and animals. This probably explains why this fruit is considered a staple fruit in semi-arid region of the world. Generally, the carbohydrate content of date palms has been reported to largely compose of fructose and glucose $[1,3]$ which are readily metabolized in cell energy production pathways. The carbohydrate content (76.96 $\mathrm{g} / 100 \mathrm{~g})$ recorded in this study is similar to the value $(75.85$ $\mathrm{g} / 100 \mathrm{~g}$ ) reported on Nigerian date fruit (dabino) [2].and also to values (74.3 to $78.4 \mathrm{~g} / 100 \mathrm{~g}$ ) reported for different Date varieties in medinah Al-munawarrah [21] but in variance with another study on Nigerian cultivar [23].

The low moisture content observed in Niger Date fruit in this study accounts for long shelf life generally associated with Date fruits. Fruits or vegetable with high moisture contents are susceptible to spoilage and microbial invasion. Conversely, fruits or vegetable with low moisture contents have low susceptibility to microbial degradation and consequently, high durability. The low moisture content (13.4 $\mathrm{g} / 100 \mathrm{~g}$ ) observed in the examined date fruit is in consonant 
with values reported by previous studies on different varieties $[3,20,21,24] \mathrm{c}$. It however differs from that obtained by Agboola and Adejumo [23].

The Niger cultivated date palms, like cultivars from some other countries has low fat content [3, 20, 21, 24]. In light of this, Date fruit cannot be considered as source of oil for industry but more importantly, it can be recommended as part of diet for patients with cardiovascular disease. The health recommendations and reports on diets call for the replacement of high fatty food with increase fruit intake in healthy or in some disease condition such as cardiovascular disease and digestive disorders.

Vitamin C, E and A play key role in non enzymatic, endogenous antioxidants defence mechanism against oxidative stress $[25,26]$. The amounts of vitamins $\mathrm{C}$ and $\mathrm{A}$ determined in Niger date fruit are quite small and not sufficient for the fruit to possibly function as a source of these vitamins to the body.

Mineral analysis of Niger date fruit showed high content of potassium $(360.79 \mathrm{mg} / 100 \mathrm{~g})$, calcium $(37.45 \mathrm{mg} / 100 \mathrm{~g})$ and phosphorus $(27.30 \mathrm{mg} / 100 \mathrm{~g})$. The values of $\mathrm{K}^{+}$and $\mathrm{Ca}^{2+}$ obtained in this study are similar to those reported on different cultivars of Date palm fruits [21].

Potassium plays significant role in a number of metabolic and physiological processes. Intake of diet rich in potassium and low in sodiumlike Niger date fruit may offer remarkable antihypertensive effect among other health benefits. The role of calcium and phosphorus in bone formation and development is well established. Their substantial amounts in Niger date fruitmake the fruit a natural means of preventing bone disorders like osteoporosis and osteomalacia.

The phytochemicals present in plants are majorly responsible for the pharmacological and biological activities they elicit. The pytochemical profile of Niger date fruit (phoenix dactyliferaL) showed high amount of flavonoids, alkaloids anthraquinone and tannins but relatively low saponin and terpenoid contents. The presence of these phytochemicals in Niger date fruit may suggest some medicinal properties which are yet to be exploited.

Flavonoids have been shown to have antibacterial, antiinflammatory, anti-allergic, anti-viral and antineoplastic properties. The high alkaloid content of Niger date fruit could be contributory to the longevity and pharmacological properties of the fruit. Tannin found in date palm fruit might be of pharmacologically useful as astringents. The anstringent property of tannin had been reported to have protective role on underlying tissues thereby improving wounds healing [27]. Tannins may as well help against microbial degradation of dietary proteins in the rumen. Saponins have been shown to have tumor inhibitory property on experimental animals. Plant Terpenoids are of important in pharmacy because of its wide use as anti-malaria.

\section{Conclusion}

Niger cultivated date palm is a good source of carbohydrate and essential elements (potassium, calcium and phosphorus). Health promoting compounds like flavanoids and alkakoids are also abundant in the fruit. Overall, the data obtained from this investigation did not show much difference between Niger Date palm fruit and some other previously studied cultivars (Date palms from different countries) vis-a-vis phytochemical and nutritional compositions.

\section{Acknowledgements}

The authors appreciate the technical assistance of Mrs Hassan J., Ms. Ekeolu B.M., and Mr. Fashina A.O.

\section{References}

[1] Myhara RM, Karkalas J, Taylor MS. The composition of maturing Omani dates. Journal of the science of food and Agriculture 1999; vol79:pp1345-1350.

[2] Sadiq IS, Izuagie T, Shuaibu M, Dogoyaro AI, Garba A, Abubakar S. The Nutritional Evaluation and Medicinal Value of Date Palm (Phoenix dactylifera). Int J Modern Chem 2013; vol4:pp147-154.

[3] Al Farsi MA, Lee CY. Nutritional and functional properties of dates: a review. Critical Reviews in Food Science and Nutrition 2008; vol48: pp877-887.

[4] Sawaya WN, Safi WM, Black LT, Mashadi AS, AlMuhammad MM. Physical and chemical characterization of the major Date varieties grown in Saudi Arabia II. Sugars, Tannins, Vitamins A and C. Date palm Journal 1983; vol2: pp183-196.

[5] Augstburger F, Berger J, Censkowsky U, Heid P, Milz J, Streit C. Date Palm. . Naturland. Germany.2002.

[6] Ali-Mohamed AY, Khamis ASH. Mineral Ion Content of the Seeds of Six Cultivars of Bahraini Date Palm (Phoenix dactylifera). Journal of Agricultural and Food Chemistry 2000; vol52:pp 6522-6525.

[7] AOAC. Official methods of analysis. 17 ed. Gaithersburg: Association of Official Analy. Chem; 2000.

[8] Harris LJ, Ray SN. Determination of plasma ascorbic acid by 2, 6-dichlorophenol indophenol titration. Lancet, 1935; vol 1:pp462.

[9] Arnon DI. Copper enzymes in isolated chloroplast, polyphenol oxidase in Beta vulgaris. Plant Physiol, 1949; vol 24:pp1-15.

[10] Garrett WN, Johnson DE. Nutritional energetics of ruminants. J Anim Sci 1983; vol57:pp478.

[11] Allen S. A rapid and safe method of estimating nanomole quantities of $\mathrm{P}, \mathrm{K}<\sup >+</ \sup >, \mathrm{Na}<\sup >+</ \sup >, \mathrm{Ca}<$ sup $>2+</$ sup $>$, and $M g<\sup >2+</$ sup $>$ in plant material by perchloric acid digestion. Analytical biochemistry 1984; vol138:pp346-353.

[12] Sofowora A. Medicinal plants and traditional medicine in Africa. John Wiley and sons 1993:pp112-142. 
[13] Trease E, Evans WC. A text book of Pharmacology 13 ed. London: Baillieritindal; 1984. pp. $61-62$.

[14] Harborne JB. Phytochemical methods. London: Chapman and Hall; 1973. pp. 49-88.

[15] Obadoni BO, Ochuko PO. Phytochemical studies and comparative efficacy of the crude extracts of some homeostatic plants in Edo and Delta states of Nigeria. Glob J Pure Appl Sci 2001; vol8:pp203-208.

[16] Boham BA, Kocipai-Abyazan R. Flavonoids and condensed tannins from leaves of Hawaiian Vaccinium vaticulatun and V. calycinium. Pacific Sci 1974; vol 48:pp458 -463.

[17] Soladoye MO, Chukwuma EC. Quantitative phytochemical profile of the leaves of Cissus populnea Guill. \& Perr. (Vitaceae) - an important medicinal plant in central Nigeria. Archives of Applied Science Research 2012; vol4 pp200-206.

[18] Van-Burden TP, Robinson WC. Formation of complexes between protein and tannin acid. J Agric Food Chem 1981; vol1:pp77.

[19] Mboso OE, Eyong EU, Odey MO, Osakwe E. Comparative phytochemical screening of Ereromastax speciosa and Ereromastax polysperma. J Nat Prod Plant Resour 2013; 3:3741.

[20] Mashadi AS, Al-Muhammad MM. Physical and chemical characterisation of the major date varieties grown in Saudi Arabia ii. Sugars, tannins, vitamins a and c wn sawaya, wm safi, lt black. The date palm: 183 .
[21] Assirey EAR. Nutritional composition of fruit of 10 date palm (Phoenix dactylifera L.) cultivars grown in Saudi Arabia. J Taibah Univ Sci 2014.

[22] Booij I, Piombo G, Risterucci JM, Coupe M, Tho-mas D, Ferry M. Study of Chemical Composition of Dates at Different Stages of Maturity for Varietals Char-acterization of Different Cultivars of Dates. Fruit-Paris 1992; 47:667-78.

[23] Agboola OS, Adejumo AL. Nutritional composition of the fruit of the Nigerian wild date palm, Phoenix dactylifera. World J Dairy \& Food Sci 2013; 8:196-200.

[24] Sourial GF, Khalifa AS, Gaafar SI, Tewfik AA, Mousa IA. Evaluation of Some Selected Date Cul-tivars Grown in Sharkiya Vine. Egypt. . Proceeding of the Second Symposium of the Date Palm in Saudi Arabia. Al-Ahsa: Chemical Composition; 1986. p. 141-52.

[25] Garcia-Bailo B, El-Sohemy A, Haddad PS, Arora P, BenZaied F, Karmali M, et al. Vitamins D, C, and E in the prevention of type 2 diabetes mellitus: modulation of inflammation and oxidative stress. Biologics: targets \& therapy 2011; 5:7.

[26] Mc Nulty H, Jacob RF, Mason RP. Biologic activity of carotenoids related to distinct membrane physicochemical interactions. Am J Cardiol 2008; 101:20-9.

[27] Tyler VE, Braddyu LR, Roberts JE. A Textbook of Pharmacology Lea and Pernoager. Philadelphia 1998:85-90. 